Review

\title{
A Review of Residential Buildings' Sustainability Performance Using a Life Cycle Assessment Approach
}

\author{
Shahana Y. Janjua ${ }^{1, *}$, Prabir K. Sarker ${ }^{1}$, Wahidul K. Biswas ${ }^{2}$ \\ 1 School of Civil and Mechanical Engineering, Curtin University, Perth, 6102, \\ Australia \\ 2 Sustainable Engineering Group, Curtin University, Perth, 6102, Australia \\ * Correspondence: Shahana Y. Janjua, Email: s.janjua@postgrad.curtin.edu.au.
}

\section{ABSTRACT}

Achieving sustainable buildings is a challenging task. Building sustainability involves "green building" design and construction, taking account of both environmental elements and economic benefits, along with social obligations to the society we live in. This article aims to critically review and analyse studies of the building and construction industry that deal with aspects of sustainability, including environmental life cycle assessment, life cycle costing, social life cycle assessment and cleaner production strategies, and to examine the research gaps in order to generate recommendations for further research. About 807 refereed research articles on residential buildings published over the last 10 years (2009-2019), were downloaded, having been searched from online databases (including Scopus, Web of Science, ScienceDirect and Compendex) using keywords. Building materials, embodied energy and operating energy were found to contribute chiefly to the environmental and socio-economic objectives of the construction industry. Many studies covered only the life cycle tools (such as environmental life cycle assessment, life cycle costing, and social lifecycle assessment) used in the sustainability assessment process. The "carbon footprint" concept is the most commonly used indicator in building sustainability assessments, underlining the urgent need to deploy more diverse environmental impact categories in order to avoid trade-offs among environmental, social and economic objectives. The social life cycle assessment tool needs a

\section{G Open Access}

Received: 15 April 2019 Accepted: 18 June 2019

Published: 19 June 2019

Copyright $(92019$ by the author(s). Licensee Hapres, London, United Kingdom. This is an open access article distributed under the terms and conditions of Creative Commons Attribution 4.0 International License. methodological breakthrough to improve its application in the building industry. In most of the studies, only an approximate evaluation of buildings' service life is the main consideration in life cycle assessments, while the important factor of the quality of the materials used in buildings is often neglected. However, a methodological approach to estimate the service life of structures that considers the durability of different building components would provide a more realistic life cycle assessment. Hence it would be judicious to address the thematic and methodological gaps identified in this paper, thereby optimising the understanding and communication of life cycle outcomes in building sustainability.

KEYWORDS: sustainability; life cycle assessment; building; sustainability indicators; service life 


\section{ABBREVIATIONS}

AHP, analytical hierarchy process; BIM, building information modelling; C \& D waste, construction and demolition waste; CLT, cross-laminated timber; $\mathrm{CMoC}$, cost model of construction; ELCA, environmental life cycle assessment; EMoC, environmental model of construction; EPD, environmental product declaration; GHG, greenhouse gas; GWP, global warming potential; HVAC, heat, ventilation and air-conditioning; LC3, limestone calcined clay cement; LCA, life cycle assessment; LCC, life cycle cost; LCI, life cycle inventory; LCSA, life cycle sustainability assessment; PET, Polyethylene terephthalate; PFA, pulverised fuel ash or fly ash; SL, service life; SLCA, social life cycle assessment; SMoC, social impact model of construction. TBL, triple bottom line

\section{INTRODUCTION}

Sustainability has for some time been a field of interest to researchers, one which is predominantly driven by environmental deterioration, social advancement and community engagement. Sustainability has thus become a key topic among scholars, regulators, and businesses. Systematic studies of sustainability have helped enterprises to adopt strategies to meet the expectations of stakeholders, as well insure, sustain and embellish social assets and natural resources for future generations [1]. Sustainability is an ecologically focused development that enhances our capacity to conserve resources for future generations. Current economic and human activities are unsustainable as their economic benefits are not aligned with social and environmental benefits. The complex and interlinked structure of sustainability entails wise natural resource utilisation, social sensitivity and economic realism as we try to turn this crisis into a positive challenge for the future.

The construction sector, which promotes economic growth and enhances society's wellbeing by providing shelter and employment, also contributes significantly to resource depletion, and to associated greenhouse gas (GHG) emissions [2-4]. World-wide, the annual energy consumption and GHG emissions of buildings and the building construction sector are $30 \%$ and $25 \%$ respectively [5]. The construction sector alone contributes significantly to global and local economic growth, to the tune of more than $\$ 8.8$ trillion per year [6]. The sector uses about one third of global resources and generates approximately $40 \%$ of all solid wastes [7]. Building construction consumes $25 \%$ of wood, $16 \%$ of water and $40 \%$ of aggregate per year, according to some reports [8]. Some of the most commonly used construction materials, like aluminium, steel, glass, plastic, and cement, are energy-intensive materials [8]. The building industry is Australia's fastest growing industry, consuming about $21 \%$ of energy and generating 20 million tonnes of construction and demolition (C\&D) waste per year-i.e., 30\% of the nation's annual waste generation [9]. On the other hand, the construction industry creates more than one 
million job opportunities annually and contributes $8 \%$ of Australia's GDP [10].

It is estimated that the construction industry will consume $21 \%$ of global energy and 32\% of operational energy for buildings by 2040, due to urbanisation in non-OECD countries. About $60 \%$ of the total planned infrastructure needs to be built by 2050, which will deplete earth's resources exponentially [11]. Yet the building sector has great potential to reduce GHG emissions in a short period [12]. Green building, sustainable building, and smart building concepts are emerging globally, designed to ensure buildings' sustainability performance. Life cycle assessment (LCA) has been widely used across the globe to assess the economic and environmental impacts of the building sector. Life cycle sustainability assessment (LCSA) is a comprehensive LCA tool used to assess the overall sustainability performance of buildings by integrating environmental, economic and social measures [11]. Sustainability indicators facilitate the measurement of buildings' sustainability performance and set criteria for that performance. All these assessments have been based on the average service life of the buildings concerned [13,14]; hence this additional review has now been carried out to determine whether this consideration of average service life may affect the sustainability assessment process.

Although buildings are one of humankind's basic needs, they are also responsible for environmental degradation, including air, water and land pollution, localised health issues and resource depletion. The objective of the sustainable development of buildings is to comply with environmental, social and economic standards. A sustainable building expresses a design philosophy that strives to enhance effective resource efficiency, and reduce negative impacts on human wellbeing and dignity, in a costeffective manner. A comprehensive framework is required to assess the triple bottom line (TBL) objectives of sustainability over the entire life span of buildings. In this paper, the current state of sustainability assessment tools for assessing residential buildings over their entire life has been reviewed from both the environmental and socio-economic perspectives. Additionally, this paper discusses sustainability indicators for the three main objectives of sustainability assessment, and aims to identify research gaps, formulate research questions, and develop an improved sustainability framework for the building industry.

\section{METHOD OF REVIEW}

A meticulous literature review was conducted on the topics of the sustainability assessment of residential buildings, construction materials, and assessment tools such as environmental life cycle assessment (ELCA), life cycle costing (LCC), social life cycle assessment (SLCA), indicator-based performance of buildings, and cleaner production strategies. Secondly, a review of the service life of buildings was conducted, as this parameter has a significant bearing on the conservation of natural resources. Thirdly, buildings made of both conventional (brick, timber, steel, concrete blocks) 
and by-product based materials (green concretes with partial replacement by $30 \%$ fly ash and $30 \%$ ground granulated blast slag) were investigated to determine how the choice of materials affects buildings' service life and their sustainability performance [15]. The literature review consisted of four steps:

1. Keywords and the criteria for searching available databases were determined.

2. The collected papers were then listed using excel sheets, and duplicates were removed from the list.

3. The abstracts of the articles that were found through search engines were thoroughly reviewed to conduct an initial screening process.

4. The final list of articles related to residential buildings at all stages of life cycle assessment was then categorised into two sections: building materials and service life, and sustainability of residential buildings from the TBL perspective.

The literature review was based on the latest research findings published during 2009-2019, with the aim of identifying the gaps in the existing research on the sustainability assessment of residential buildings. The review was conducted using four research databases: Scopus, Web of Science, ScienceDirect and Compendex. The keywords used when operating the search engines were: sustainability; residential buildings; life cycle assessment; life cycle sustainability assessment; social life cycle assessment; sustainability assessment; sustainability indicators; triple bottom line; sustainability performance; environmental certification; service life; life-span and re-use in construction. The scope was then narrowed down by using the following criteria to include publications in the survey:

- Scientific research publications and documents published by recognised bodies (e.g., government departments, United Nations Environment Programme (UNEP), over the past 10 years (2009-2019));

- Peer reviewed articles (refereed journals, and conference proceedings, and guidelines published by recognised bodies (e.g., ISO));

- Published in English.

A total of 807 publications were found to address sustainability aspects of residential buildings during the past decade, at different levels. Of these publications, only three were on SLCA and only five on LCSA as applied to residential buildings, while $80.4 \%$ of the publications discussed ELCA and $18.6 \%$ addressed both the environmental and economic aspects of sustainability using ELCA and LCC respectively.

\section{BUILDING MATERIALS AND SERVICE LIFE}

\section{Building Materials}

Building sustainability is difficult to quantify and define when reviewing a wide variety of construction methods, installation techniques, 
raw materials and manufacturing systems. Naturally, building materials are the main element in life cycle assessments, right from their initial extraction in raw-produce form to their final disposal to landfill or recycling after a building's life has ended. The assessment process takes into account every input or output involved in materials production, consumption and disposal, from energy, people and money, to environmental impacts. Almost all building materials come from nature, whether directly (natural materials) or indirectly (synthetic materials). A material closer to nature is more sustainable, because it involves less processing, less transportation, less energy consumption and fewer harmful chemicals [16]. Besides considerations of environmental impacts, building material sustainability also depends on factors like renewability, price, life span, resource availability, local availability, non-toxicity, thermal resistance and recycling potential. At the early design stage, the designer should be aware of the traditional perceptions of the characteristics of materials-such as tactile, thermal, acoustic, visual and olfactory etc. [17]. Technically, there are other factors to be considered in building design, such as cost, durability, market trends, availability, reliability, stakeholders, aesthetics, indoor quality and comfort, cultural aspects, social concerns, and end-user emotions [17-21]. Materials selection means weighing up social, economic and environmental factors alongside technical aspects of construction [22]. Materials manufacturers are now investing in sustainable products with minimal environmental impact, yet also capable of enabling advanced technology [23].

The growth of the construction and building industries as urban development proceeds has led to increased demand for materials, resulting in natural resource exploitation [24]. In addition to low carbon materials, researchers are also focused on renewable materials, including bamboo, stone, wool, and straw bale [25-27]. Ajayi et al. [28] suggested that sustainable materials could reduce the impact of operational energy due to their energy conserving nature. De Luca et al. [29] supported the importance of the innovative use of materials like cement, wood, glass and ceramics in reducing the environmental impact of the building industry. A study by Harish and Kumar [30] estimated that $20 \%-50 \%$ of the usual energy expenditure can be saved by proper materials selection for a building envelope. Lawania and Biswas [31] studied 60 building envelope options for a typical West Australian house and showed that a building envelope with cast-in-situ sandwich walls containing Polyethylene terephthalate (PET) foam core, concrete tile roof cladding and doubleglazed windows, offers the lowest embodied energy consumption and GHG emissions. A study of reinforced concrete buildings with limestone calcined clay cement (LC3) and pulverised fuel ash or fly ash (PFA) showed that LC3 and PFA have a significantly lower carbon footprint than conventional concrete systems [32]. A case study for four Brazilian residential buildings showed that steel, concrete and ceramic tiles have the highest environmental impacts [13]. Huang et al. [33] and 
Glover et al. [34] also concluded that concrete and steel have the highest embodied energy among wood, steel and concrete. Petrovic et al. [35], studied a single-family house in Sweden, over a 100-year period, and concluded that concrete slab has the highest carbon footprint, while wood and cellulose have the lowest environmental impact. A study of multi-storey residential buildings with structural material options of cross-laminated timber (CLT), prefabricated timber modules (modular) and precast concrete demonstrated that CLT and modular buildings offer $37 \%$ and $17 \%$ lower life-cycle primary energy consumption respectively compared to precast concrete [36].

Increased construction activity is exacerbating raw materials scarcity and emissions associated with the transportation and manufacturing of building materials [37]. Industrial by-products and waste materials like waste foundry sand [38,39], ground granulated blast furnace slag [40,41], steel slag [42,43], imperial smelting furnace slag [44], copper slag [45,46], bottom ash [47,48], class F type fly ash [48,49], silica fumes [50], palm oil clinker [51], rice husk ash [52,53], bagasse [54,55] and composites [56] have been found to improve buildings' structural and environmental performance when used instead of fine aggregates. Apart from generating industrial by-products, the recycling of C\&D waste can also help reduce environmental impact and costs attributable to building materials [57]: recycled materials like ceramic and PET reduce the porosity of mortar, for example [58,59]. Research has shown that the addition of both industrial by-products and recycled aggregates can reduce a building's carbon footprint $[37,49,60]$. However, the transportation of these materials sometimes increases the carbon footprint [61-64]. This is why such materials need to be sourced locally, a critical factor for materials sustainability.

Materials selection should be based on TBL (economic, social and environmental aspects of impact) implications as well as structural stability. Industrial by-products and recycled construction materials provide a way to reduce the pressure on the natural resource extraction currently necessary to meet the increasing demand of the construction sector, yet the local sourcing of these materials is important to reduce the indirect TBL impacts on the building project.

\section{Building Service Life}

The service life (SL) of buildings plays a significant role in their LCSA. The building and building components deteriorate naturally with age. Knowledge of deterioration mechanisms and degradation agents helps to predict the service life of a building and its components. LCAs are carried out based on the life span of buildings. However, most LCA studies have considered a life span to be between 30 and 70 years, with the most common assumption being 50 years [15,65,66]. Out of 807 articles reviewed, only two $[15,65]$ have used the estimated SL of buildings in order to assess the environmental impacts of residential buildings. This 
discrepancy in defining life span, due to assumptions about a building's end of life and incorrectly recorded intervals of repair and maintenance, has created uncertainty in LCA results.

The SL of a building can be estimated by theoretical or empirical methods [67]. Empirical methods deploy simple and robust tools, using the deterioration and degradation of materials to predict a building's SL. Different SL assessment approaches have been used for building materials and components. Grant et al. [65] advocated the empirical method as the most accurate. The "factor method" is a deterministic method devised to estimate the SL of buildings. It uses seven factors to estimate the SL of the building and building components under particular conditions, considering climatic conditions and the building's location [68]. Various studies have used SL prediction methods to estimate the SL of building materials. Madrigal et al. [69] used a factor method to estimate the SL of building envelopes. Emidio et al. [70] analysed 269 stone claddings in Portugal using the factor method and concluded that SL varies according to user demands, building use and funds availability for repair work. Souza et al. [71] applied the factor method to estimate the SL of ceramic tiling in Brazil, using both deterministic and probabilistic approaches. The study found that depending on the data quality, and the materials' exposure to the environment, both (deterministic and probabilistic) approaches produce consistent results. Pillai et al. [32] used accelerated tests to determine the SL of LC3 and compared the annual carbon footprint of conventional concrete with LC3 concrete. The LC3 concrete's annual footprint was found to be much lower than that of conventional concrete, owing to lower clinker quantity and a significantly high SL.

Nath et al. [49], used a deterministic method to predict the SL of conventional concrete and concretes containing 30\% and 40\% cement replacement by a Class F fly ash, and concluded that the fly ash increases the SL, and reduces both the carbon footprint and the embodied energy of the concrete. Another study proposed an SL prediction model using an accelerated test to study the effects of the intensity and wavelength of light on photovoltaic laminate material [72]. Ligotski et al. [73] investigated the SL of adsorptive heat, ventilation and air-conditioning (HVAC) filters used to improve indoor air quality, using a probabilistic method. Three activated carbon-based filter media were studied, and good agreement was found between the prediction data and the relevant S-curve. The SL of 100 churches was studied by Prieto et al. [74], using multiple linear regression and fuzzy logic models to determine a maintenance and preventive conservation action plan for cultural heritage buildings. Rauf and Crawford [75-77] studied the impact of SL variation on the environmental assessment of buildings. This study found that the embodied energy of a building may increase by one third due to maintenance and replacement activities, if the building's SL is not considered at the early design stage of a project. Grant et al. [65] studied the SL of building envelopes to make annual comparisons of the 
environmental impacts and concluded that environmental impacts are primarily dependent on the intensity and frequency of maintenance, and on the indicators used. Janjua et al. [15], used the factor method to determine the SL of buildings and building components and conducted an ELCA study of 12 buildings made of different building materials, to investigate the relationship between SL and the environmental impacts of buildings. This study concluded that the longevity of a building's SL can produce sustainable results if all the building components have a comparatively similar SL, thanks to a lower level of building component replacements.

The SL of a building plays an important role in the assessment of TBL sustainability impacts after the building actually comes into use, as buildings made of different materials behave differently in terms of durability and are capable of reducing or enhancing the TBL impacts. The SL prediction tool has been widely applied to building materials and building components, but there is still a gap in the literature when it comes to the application of SL prediction to life cycle assessments.

\section{SUSTAINABILITY IN RESIDENTIAL BUILDINGS}

Sustainability is the ultimate objective of all product development. According to the Klöppfer [78], sustainability has three main aspects: economic, social and environmental, known as the TBL objectives. An LCSA is a comprehensive assessment of these three crucial impacts attributable to a product [78].

\section{Environmental Life Cycle Assessment}

"Life cycle assessment (LCA) is a tool to assess the environmental objectives and potential impacts associated with the prediction and use of a product/system, by developing an inventory of relevant inputs and outputs of a product system; evaluating the potential environmental impacts; and interpreting the results of the inventory analysis and impact assessment phases" [79]. With the development of tools like SLCA and LCSA, environmental life cycle assessment is now known as ELCA. Based on the ISO guidelines series 14040-44 [79], the ELCA process scrutinises the environmental inputs/outputs of products at all life cycle stages, including: (1) the pre-use stage (extraction of raw materials for materials manufacturing, transportation to construction sites, construction), (2) the use stage, and (3) the demolition and disposal stage. The process also requires four prescribed steps: defining goals and scope; creating a life cycle inventory; assessing the environmental impacts, and interpreting the results $[14,80]$.

The idea of sustainability assessment started in 1960, when there was already research on LCA, then mainly used to compare products at the manufacturing stage. In 1969, the first LCA study (unpublished) was conducted by Midwest Research Institute for the Coca Cola Company, examining emissions, resources, and waste generation for different 
beverage containers [81]. In the construction sector, LCA was first introduced by Bekker, identifying the need for renewable energy [82]. The environmental implications of building materials were first assessed using an LCA tool [83]. UNEP and the Society of Environmental Toxicology and Chemistry (SETAC) introduced the life cycle concept to expedite the use of LCA. An Environmental Product Declaration (EPD), is one of the life cycle concept applications based on LCA. EPDs are statements of quantified, verified and registered environmental data about a product, intended to provide transparent and reliable information on a product's environmental impact throughout its life. EPDs are helpful in the selection of eco-friendly materials for sustainable building design [84]. Environmental certifications are another application of the life cycle concept in the building sector, created to measure, quantify and assess the sustainability performance of buildings. CASBEE (Japan); Green Star (Oceania); HK-Beam (Hong Kong); Passivhaus (Sweden); LEED (America); BREEAM (Europe), and DGNB (Germany) are just a few examples of certification systems using ELCA [85-88].

ELCA has been used to assess and improve buildings' performance through the pre-use, use and post-use stages of its life. The pre-use stage includes the extraction, manufacturing and transportation to site of materials. The use stage is the occupancy phase, while post-use involves demolition, and recycling of materials. ELCA studies mostly focus on the various life cycle stages independently, instead of holistically considering all stages together. Only one third of the reviewed studies on ELCA covered all stages of the LCA, with the remaining two thirds focused exclusively on only one stage: $25 \%$ on the pre-use stage; $29 \%$ on the use stage, and $13 \%$ on the post-use stage. For a long time, LCA studies of buildings have focused primarily on energy efficiency and emissions associated with the use stage [89], leading to extensive research into the energy-efficient operation of buildings. Owing to a recent research focus on buildings' operational stage, attention has shifted to the extraction and manufacturing of construction materials, and the construction stage [90]. Building materials, embodied energy, operating energy and C\&D waste are the common sustainability indicators used in sustainability assessments of the construction industry, with the carbon footprint measure found in 97.6\% of articles on ELCA.

Most of the studies of buildings over the past decade have assumed an SL of 50 years for the building and building components, regardless of the materials actually used [91]. Due to this assumption on SL data, few studies have addressed the energy consumption and subsequent GHG emissions resulting from maintenance or refurbishment activity at the buildings. The energy consumed during repair, refurbishment or maintenance activities can substantially exceed initial embodied energy, if an assessment of the durability of the building materials used is neglected at the design stage [75]. Rauf and Crawford [77] have shown that the energy calculations may vary by $30 \%$ if there is no consideration of estimated SL. 
Building material properties play an important role in the sustainable design of buildings [92]. ELCA helps to determine the cumulative effects of building materials on building performance. A thorough LCA study comparing recycled and ordinary concrete of the same strength has showed that recycled concrete is only slightly better in terms of carbon emissions. The ELCA tool helps to determine the differing energy and environmental performance of buildings using different building materials, whether consisting of virgin materials and/or by-product sources [93]. Gámez-García et al. [94] assessed 20 types of the external wall system that is conventional at the pre-use stage for residential buildings in Spain and concluded that the physical specifications of components, along with the materials selection process, contribute decisively to a building's environmental optimisation. The thermal performance of buildings has been assessed based on the building materials used, by Maalouf [95], Lawania [14], and Intini [96]. These studies examined polystyrene fibre products made from PET bottle flakes, unanimously showing that wasteproduct materials such as PET can reduce environmental impact across the life cycle of a product, and minimise the damage created by the system under study. An ELCA study of the structural systems of residential buildings in Sweden concluded that pre-engineered buildings have less energy impact in the pre-use and use stages, compared with the impact of conventional concrete systems; the study also found that a combination of sustainable structural materials and an efficient energy supply system results in the best building design [36]. Schmidt and Crawford [97] proposed an integrated framework for life cycle costs and GHG emissions in their study of different glazing options for a typical Australian detached house. The framework demonstrated the prevalent trade-off between cost and environmental impact in design decisions. Vivian Tam et al. conducted a review of LCA software designed for environmental assessments. GaBi and SimaPro were found to be the most widely used software programs, along with green energy rating tools. None of these software programs had yet been found capable of revealing the errors in environmental impact assessments [98]. The selection of material databases to use in LCA is vital to the assessment of environmental impacts, in order to reduce the uncertainties in findings that may result from a project's location and the database source. GaBi Database and Ecoinvent are two European databases that stand out for their broad range of materials data, usability, and integrity [99]. Ecoinvent has been found to be the most suitable database for construction projects, for all categories of construction materials [100,101]. GaBi Database is a cradle-to-gate database and includes all categories of construction materials, with regular annual updates [102].

The demolition and disposal of buildings increase the environmental burden due to C\&D waste. However, recycling and re-use can help recover the embodied energy by $32 \%-42 \%[76,103,104]$. A study of LCA for the endof life stage of residential buildings showed that with steel recycling alone, 
it is possible to reduce the global warming impact by $89 \%$ and the minerals extraction impact by $73 \%$ [105]. Ghose et al. [106], found that the re-use of building materials in New Zealand could reduce environmental impact by $15 \%-25 \%$ as compared to using recycled materials (5\%).

Although ELCA can determine impact in different environmental impact categories, life cycle energy consumption and carbon footprint are the most commonly assessed environmental impacts for the building sector [107,108]. Most of the studies use an assumed SL to assess the whole life cycle impacts of buildings (boundary conditions were defined by the particular objectives of each study). Finally, the ELCA tool was found useful to identify improvement strategies that can reduce environmental impacts. This form of LCA can also be used to discern the economic and social implications of environmental options, for overall sustainability assessment.

\section{Life Cycle Costing}

Life cycle costing (LCC) is a salient indicator for measuring the economic performance of a project. Klöppfer [78] described LCC as "a logical counterpart of LCA for the economic assessment”. The LCC tool was developed before LCA [109], hence its relationship with LCA is quite recent. LCC was used in the 1960s for cost analysis during the proposal phase of a project to safeguard investment. However, right from the beginning of the 21st century, the LCC has become as crucial as ELCA to a structure's sustainability. LCC is useful to determine the relative costeffectiveness/cost-competitiveness of various environmentally-friendly options [110]. LCC can be conducted using the same system boundaries as ELCA [111]. Due to its lack of computational structure, the use of LCC for sustainability assessment is quite often criticised [112]. LCC is challenging because many stakeholders are involved in any product life cycle; hence it is difficult to differentiate between physical and financial costs, resulting in double counting among TBL dimensions. In the building industry, LCC deals with embryonic capital, settlement, operational and disposal costs, and uses the same material and energy inventories as for ELCA. A number of research studies have developed models and frameworks to assess the economic performance of the built environment including examinations of transportation projects [113], residential buildings [114], and industrial buildings [111,115]. The concept of "green buildings" is constrained by the high costs entailed in attaining environmental and social sustainability [116,117]. The LCC process provides an important checklist for assessing the economic sustainability of a building project [118]. Ahmad and Thaheem [119] proposed an economic sustainability framework for residential buildings that considered LCC to be a "traditional indicator", while they characterised affordability, adaptability and manageability factors as "non-traditional indicators". Their framework was tested on three residential buildings and used the building information modelling 
(BIM) tool to assess the cost perceptions underpinning the project as part of the process toward ensuring eco-friendly buildings. Babaizadeh et al. [120], used LCC along with LCA to assess the sustainability performance of exterior window shades/shutters in different climatic zones of the USA, concluding that timber shades were an eco-efficient option with reduced cost and lower environmental impact. Allacker et al. [121] concluded after studying the LCC of 16 low-energy residential buildings in Belgium that external environmental costs contribute only $5 \%-10 \%$ of such buildings' LCC; they found that this refutes the view that making a 'green choice' may render housing unaffordable. A study in Hong Kong considered LCC in its quest to find a sustainable maintenance option for building repairs and the retrofitting of residential buildings, identifying materials with a low carbon footprint and employing local labour resources [122]. Mahmoud Dawood [123] proposed a framework integrating genetic algorithms and BIM to discover the building components with the least LCC at the building design stage. Another study used LCC to determine the feasibility of using water conservation components in mass housing projects, and concluded that the feasibility of green construction depends on the incentives and policies of the relevant government and varies according to geographic location and climatic zone [124]. Tam et al. [125] used LCC analysis to study green building materials, conducting a detailed analysis of different timber types used in residential building construction in the Australian context. This study presents a methodology for finding the best materials for green buildings that also entail minimal cost. Lawania and Biswas [111] studied 20 building envelope options using LCC along with ELCA to compare conventional buildings with those designed with integrated solar photovoltaic systems and solar water heating. This study concluded that a GHG emission reduction of up to $50 \%$, as well as cost savings of approximately $8.5 \%$, could be achieved by using renewable resources in the use stage of a building. Yoshida and Sugiura [126] studied the effect of green factors (planting, long life span, energy efficiency and resource efficiency) on green buildings, using LCC to compare the investment return or pay-back period for such green factors. This study found that green building designs command a price premium thanks to these buildings' long-life span.

With the development of the green building concept, LCC has gained importance in green building certification systems [127]. There are cost implications in the environmental improvement of buildings. LCC could be used to come up with least-cost green building options and to identify avenues where incentives/economic instruments can be applied to make a green building project more cost-competitive and eco-efficient. However, ensuring a win-win situation that involves the selection of cost-effective but also environmentally friendly options is a challenge. 


\section{Social Life Cycle Assessment}

Social life cycle assessment (SLCA) determines the social objectives of the sustainability of a product. It particularly addresses the requirements of various stakeholders in the life cycle stages of a building, including the end-user, suppliers, community, builders and designers. SLCA follows the four steps of ELCA including goal and scope definition, compilation of inventory, impact assessment, and interpretation of results. In 1996, O'Brien et al. [128] extended ELCA for the first time by incorporating the new factor of political and social influences on environmental impacts. The idea of integrating SLCA with LCC and LCA emerged in 1999 at a SETAC conference where social welfare was suggested as a social impact factor in ELCA studies [129]. In 2009, UNEP/SETAC published methodological sheets and guidelines for the SLCA of products [129]. This tool successfully identified social hotspots in various industrial cases by interviewing stakeholders for cradle-to-grave life cycle studies of specific products, such as laptop computers (e.g., workers' benefits, security and safety, and healthy living conditions for the local community)[130]; vehicle fuels (e.g., child labour, health and safety, and fair salary)[131]; palm oil biodiesel products (e.g., exploitative labour relations, wellbeing of the local community)[132]; palm oil industry products (e.g., employment opportunities, fair salary and access to information)[133]; bamboo bicycle frames (e.g., child labour, working hours, and local employment)[134]; waste management (e.g., illegal waste deposits)[135]; and fertilisers (e.g., labour laws, occupational hazards and accidents, and local community deaths due to air pollution)[136].

The SLCA tool has not often been used in the building sector. A very limited number of SLCA studies have been conducted on residential buildings, in which mainly social welfare dimensions such as employment and human health were considered [137,138]. Hosseinijou et al. [137] used SLCA to compare the social impacts of concrete and steel, and identified the social hotspots using material flow analysis and a participatory approach. This study concluded that the social impacts are linked more to company management than to the processes and materials used. Santos et al. [139] used health and comfort of the European Standard EN 16309:2014 methodology [140] to assess how five building characteristics-the building's thermal and acoustic profiles, its indoor air quality, visual comfort and spatial aspects-affect the social performance of three experimental buildings in Portugal with varying layout, design and area coverage. Liu and Qian [141] proposed a social sustainability framework for buildings that identified workers, occupants, the local community and society as the main stakeholders, to assess two types of construction: prefabricated prefinished volumetric construction and semiprefabricated construction. The study concluded that the former outperforms the latter because it boasts the better worker protection scheme, and sophisticated technologies. An SLCA conducted by Dong and $\mathrm{Ng}$ [138] for the construction of precast buildings found that precast 
structures had negatively impacted local employment because the precast concrete components (including the façade, slab, and staircase) were imported rather than locally sourced. As in previous studies, this study also found that the inclusion of eco-efficiency practices could improve the social performance of building construction.

SLCA is an emerging tool, experiencing challenges in terms of life cycle inventory (LCI) compilation and analysis. Most of the SLCA articles reviewed considered generic national data [130], except for a few studies that used site-specific data [137]. There is not a single agreed approach to the selection of impact indicators, with UNEP/SETAC guidelines suggesting a top-down method for social LCI [129], and some other studies suggesting a participatory approach to indicator selection [142]. Stakeholder selection for SLCA depends on the research objectives, stakeholder behaviour, and confidentiality agreements signed with the company [136].

\section{Life Cycle Sustainability Assessment}

LCSA considers socio-economic and environmental impacts to assess a product as a single entity, in order to make well-informed decisions that are sustainable throughout the product's life [11]. LCSA is an emerging technique and few studies have been conducted on the LCSA of buildings. In the building sector, ELCA, LCC and SLCA have been covered individually and separately rather than collectively by most of the studies [143]. Only five studies out of 807 were found to address the TBL sustainability implications of residential buildings. A building is a complex product encompassing groups of components. Unlike other products, buildings cannot be produced based on prototype models. Each building is unique in its functional use, materials, geographic location and design. Therefore, conducting the LCSA of buildings is a complex process, due to the variability in materials, design, workmanship, location, stakeholders, and deterioration mechanisms. A sustainability assessment thus results in larger uncertainties and impacts on the reliability of results in the absence of building SL data [77]. A long-life building requires repeated component replacement and maintenance while short-life buildings eventually entail the rebuilding of the whole building, thus worsening the sustainability scenario [144]. Variation in a building's SL affects the building environmentally, socially and economically. Therefore, materials, construction methods, and building energy sources need to be selected wisely at the design phase to reduce these TBL effects. Sustainable development is an economic development conducted to fulfil the needs of the present generation without compromising future generations' ability to fulfil their needs, at the same time as conserving the earth's ecosystems and its life support capabilities [145]. The concept of sustainable performance has usually been found to be entwined with environmental performance.

The indicator-based approach is the approach that has most commonly been used to assess the sustainability performance of a product or system 
[146]. The purpose of an indicator-based approach is "to provide a measure of current performance, a clear statement of what might be achieved in terms of future performance targets and a yardstick for measurement of progress along the way" [147]. The selection of the right performance indicators, covering validity, relevance, sensitivity and measurability, is important in the sustainability assessment of a project [148]. Selecting key indicators for TBL objectives is a brainstorming task, but it makes the assessment process easier, cheaper and more timeefficient, while a larger set of indicators increases complexity and makes the assessment a time-consuming, expensive and data-intensive process [149]. Thus, an optimum number of key indicators that are aligned with sustainability objectives and standards, should be determined. Kamali et al. [150] employed LCSA based on the analytical hierarchy process (AHP) of multi-criteria decision analysis to assess modular residential buildings in British Columbia, Canada, based on 12 environmental indicators, 9 economic indicators and 12 social indicators. The authors conducted indicator selection through a group decision-making process. The indicators list was lengthened by breaking single indicators into multiindicators based on LCA stages like operational cost, maintenance cost, end-of-life cost, design and construction costs that could be covered by the LCC process. In this paper, a few management strategies (e.g., site disruption) and appropriate strategies and objectives (e.g., renewable and environmentally preferable products), are used as indicators that could contribute to the complexities and intermixing of indicator impacts. The paper has documented the application of a proposed framework for assessing the environmental performance of a case study building with an assumed SL. Although the authors conducted a comprehensive study on the environmental performance of modular residential buildings, the study did not highlight the hotspots for modular buildings to help decide further improvement strategies. The authors also did not explain the capability of their framework to investigate modular buildings and draw comparisons with other building systems.

The types of TBL indicators deployed vary with the objectives and regional perspectives of the product/system under consideration. Onat et al. [151] have used an integrated input-output hybrid LCA model to assess TBL sustainability in the residential and commercial building industries of the USA (2002), using system boundaries that include all stages of a product. The study considered 16 macro-level indicators: foreign purchase, business profit, income, government tax, injuries, fishery, grazing, forestry, cropland, carbon fossil fuel, carbon electricity, total GHG, total energy, water, and hazardous waste, categorised under TBL objectives. The authors have used only quantitative data for 2002, obtained from publicly available sources like the US Bureau of Economic Analysis, the Department of Energy, the Energy Information Administration, and the Federal Highway Administration, etc. The social aspects of sustainability should be assessed using qualitative and quantitative data, which need to 
be generic and site-specific. Site-specific qualitative data are collected through face-to-face interviews and direct observations, which also provide a clear picture of the prevalent condition of affected people that cannot easily be measured or quantified.

System boundaries in LCSA studies vary with the scope of the study. However, the three LCSA objectives, i.e., the environmental, social and economic factors, should be studied using the same system boundaries. An LCSA framework should be robust enough to analyse the TBL objectives simultaneously and explain the interdependencies among the environmental, social and economic aspects being impacted. Another study of the sustainability of residential buildings, done by Dong and $\mathrm{Ng}$ [143], examined only the pre-use stage of a multi-residential building, including materials extraction and manufacturing, and on-site construction. This study has proposed an LCSA framework combining three life cycle assessment approaches, i.e., the environmental model of construction (EMoC), the cost model of construction (CMoC), and the socialimpact model of construction (SMoC); the study has also used human health, the ecosystem, resources, materials, workers, local community and society as TBL impact categories for assessing a building's sustainability performance. The LCSA framework was based on a weak sustainability concept and the TBL objectives were discussed and interpreted independently of each other. The authors concluded that extraction and manufacturing of materials contribute more than $90 \%$ to environmental impacts and $60 \%$ to economic impacts, a far greater impact than that of actual construction activity. The SMoC showed overall positive social impacts on all stakeholders due to the project's provision of employment and its low levels of dust and noise pollution thanks to the use of precast building components that were transported and installed on-site.

The incorporation of precise building SL data in an LCSA has a significant bearing on the building's sustainability performance assessment, ultimately complementing the accuracy of LCSA results. However, none of the LCSA frameworks has addressed the variability associated with SL in the sustainability assessment process. For instance, Balasbaneh et al. [152] studied the sustainability assessment of hybrid timber-frame buildings in Malaysia, considering the following factors as sustainability indicators: global warming potential (GWP); fossil depletion potential; acidification and eutrophication; human toxicity potential; LCC; present value; wages of the foreman, and job creation. Although the authors have presented a comprehensive study on five types of hybrid timber buildings, the indicator selection for economic and social objectives is very limited. Biodiversity, land use, water consumption, and inter-generational equity, factors which are critical to natural resource assessment, were not considered in this study, which has used a fixed assumed SL of 50 years for all case study buildings, disregarding building materials properties. Another LCSA framework for residential buildings, proposed by Hossaini et al. [153], is based on the AHP approach and has 
used an assumed SL of 60 years. This framework was applied to two six-story residential buildings in Vancouver, Canada. One building was timber-framed, while the second one was a concrete structure. The framework used 18 sustainability indicators to assess the buildings' sustainability, including GWP, acidification and eutrophication, fossil fuel, habitat alteration, resources use, waste management, smog potential, and human health respiratory impact, as environmental criteria; with indoor air, occupant comfort, safety and affordability, as social criteria; and total cost as the economic criterion. This study concluded that building sustainability performance is linked to SL energy rather than construction materials. The SL was assumed to be the same for both buildings.

None of the above LCSA studies has adequately reflected on sustainability implications of residential buildings in terms of the selection of stakeholders, indicators development, site-specific data collection, nor the variation of the estimated SL of construction materials in the LCA. Contemporary LCA frameworks are not adequate for assessing all TBL objectives simultaneously. Firstly, there are several inadequacies in terms of SL assumptions, uncertainties in data quality (e.g., data collected from life cycle stakeholders), and insufficient TBL impact indicators in LCSA frameworks. None of these studies has integrated TBL objectives or provided for the application of TBL improvement strategies. Therefore, a fully holistic LCSA framework moderated by practical evaluation is essential to a comprehensive TBL sustainability assessment.

\section{LESSONS LEARNT AND FUTURE RESEARCH DIRECTION}

After a thorough review of the published literature on the sustainability performance of residential buildings, it emerges that:

1. The LCSA of residential buildings can be further improved by selecting key stakeholders, developing relevant TBL indicators, and gathering site-specific data to compile TBL inventories for sustainability assessment.

2. Few studies have been conducted to assess the TBL sustainability performance of residential buildings.

3. The sustainability assessment frameworks used so far lack a comprehensive approach to address the above-mentioned gaps. Therefore, a holistic LCSA framework is required to integrate the environmental, social and economic objectives of sustainability.

4. The system boundaries set need to consider the life cycle of all the building components and of the building itself, in order to assess the impacts of the building throughout its entire life cycle.

5. An assumed SL is the most commonly used factor when conducting life cycle assessments of buildings. This results in uncertainties in LCA assessments because the assumed maintenance and repair intervals and use stages could differ according to the building materials used. 
6. TBL indicators in existing studies found in the literature surveyed did not necessarily take into account region-specific variations. Sustainability scenarios may vary across different locations. A sustainability impact indicator, like water scarcity, child labour etc., that is considered the most important in one country may not necessarily be useful in another country.

Therefore, TBL indicator selection should be based on the factors in the region studied, and the LCSA framework should be flexible enough to handle the variation in region-specific impact indicators. This review thus confirms that there is a need to conduct LCSA studies that consider all stages of a building's life cycle and address the above-mentioned gaps, by developing a holistic TBL sustainability assessment framework for residential buildings.

\section{CONCLUSIONS}

This review confirms that LCA has been widely used to separately assess the environmental, social, and economic performance aspects of the building industry. A limited number of studies have applied LCA to determine all three TBL objectives in order to assess the overall sustainability performance of buildings. The existing frameworks were not designed to compare the sustainability performance of different buildings. Firstly, there is a need to integrate examination of the three objectives of sustainability, to obtain an overall score which will allow comparison between buildings. Secondly, this framework needs to be designed in a way that allows the identification of sustainability hotspots in order to formulate relevant improvement strategies. Thirdly, TBL indicator selection plays a crucial role as indicators vary with places, and with the socio-economic status of a region. It is therefore important to conduct a consensus survey, to select region-specific indicators that can help determine buildings' overall sustainability performance. Most importantly, the buildings' SL has a significant bearing on the sustainability of buildings constructed from varying and different materials. There are still avenues for improving the existing assessment process, in terms of developing indicators, and the integration of TBL indicators and the objectives for assessing buildings' sustainability performances. A building sustainability assessment tool should be able to handle the flexibility and complexity associated with the interaction among the three sustainability objectives in the building industry. If the industry is to improve the quality of sustainability assessments, a comprehensive sustainability framework must be developed by defining the relevant and region-specific sustainability indicators that can be measured by an LCA approach, taking into account the SL variabilities of different types of buildings made of conventional or alternative materials. 


\section{AUTHOR CONTRIBUTIONS}

Conceptualisation and methodology: SYJ, PKS and WKB; analysis: SYJ; investigation: SYJ; data curation: SYJ; original draft: SYJ; visualization: SYJ; writing review and editing: SYJ, PKS and WKB; Supervision: PKS and WKB.

\section{CONFLICTS OF INTEREST}

The authors declare no conflict of interest.

\section{FUNDING}

This research received no external funding.

\section{REFERENCES}

1. Business Council for Sustainable Development; Deloitte \& Touche; International Institute for Sustainable Development. Business strategy for sustainable development: leadership and accountability for the '90s. Winnipeg (Canada): International Institute for Sustainable Development; 1992.

2. Love PED, Irani Z. An exploratory study of information technology evaluation and benefits management practices of SMEs in the construction industry. Inf Manag. 2004;42(1):227-42.

3. Zuo J, Zhao ZY. Green building research current status and future agenda: A review. Renew Sustain Energy Rev. 2014;30:271-81.

4. Ma M, Cai W. Do commercial building sector-derived carbon emissions decouple from the economic growth in Tertiary Industry? A case study of four municipalities in China. Sci Total Environ. 2019;560(1):822-34.

5. Dean B, Dulac J, Petrichenko K, Graham P. Towards zero-emission efficient and resilient buildings. Global Status Report 2016. Paris (France): Global Allience for Buildings and Construction (GABC); 2016.

6. Trimetric. Key Highlights from Global Construction Outlook 2021. London (UK): Construction Intelligence Centre, Timetric; 2018. Report Code: GDCN0004GO.

7. United Nations Environment Programme. Towards a Green Economy: Pathways to Sustainable Development and Poverty Eradication-A synthesis for Policy Makers. St-Martin-Bellevue (France): United Nations Environment Programme; 2011. Available from: https://sustainabledevelopment.un.org/ content/documents/126GER synthesisen.pdf. Accessed 2018 Dec 25.

8. Joseph P, Tretsiakova-McNally S. Sustainable Non-metallic Building Materials. Sustainability. 2010;2(2):400-27.

9. Pickin J, Randell P. National Waste report 2016. Victoria (Australia): Department of the Environment and Energy; 2017. Available from: https://www.environment.gov.au/protection/waste-resource-recovery/ national-waste-reports/national-waste-report-2016. Accessed 2018 Dec 18.

10. Australian Bureau of Statics. Labour Force Region-SA4 Data. Canberra (Australia): Department of Jobs and Small Business_-Australian Government; 
2018. Available from: http://lmip.gov.au/default.aspx?LMIP/Downloads/ ABSLabourForceRegion. Accessed 2019 Jan 16.

11. United Nations Environment Programme. Towards a Life Cycle Sustainability Assessment. Making informed choices on Products. Paris (France): Life Cycle initiative; 2012. Available from: https://www.lifecycleinitiative.org/startinglife-cycle-thinking/life-cycle-approaches/life-cycle-sustainability-assessment. Accessed 2018 Jun 30.

12. Committee on Climate Change. Fourth carbon budget review-part 2: the costeffective path to the 2050 target. London (UK): Committee on Climate Change; 2013. Available from: https://www.theccc.org.uk/publication/fourth-carbonbudget-review/. Accessed 2019 Jun 16.

13. Evangelista PPA, Kiperstock A, Torres EA, Gonçalves JP. Environmental performance analysis of residential buildings in Brazil using life cycle assessment (LCA). Constr Build Mater. 2018;169:748-61.

14. Lawania K, Biswas WK. Application of life cycle assessment approach to deliver low carbon houses at regional level in Western Australia. Int J Life Cycle Assess. 2018;23:204-24.

15. Janjua SY, Sarker PK, Biswas WK. Impact of Service Life on the Environmental Performance of Buildings. Buidings. 2019;9:9. doi: 10.3390/buildings9010009

16. Lombard R. It's not easy being green: Difficulties in sourcing sustainable building materials. QScience Connect. 2017;2:1. doi: https://doi.org/10.5339/ connect.2017.qgbc.10

17. Hegger M, Drexler H, Zeumer M. Basics Materials. Basel (Switzerland): Birkhauser; 2007.

18. Ashby M, Johnson K. Materials and Design: the Art and Science of Material Selection in Product Design. 1st ed. Oxford (UK): Butterworth-Heinemann; 2002.

19. Crilly N, Moultrie J, Clarkson PJ. Seeing things: consumer response to the visual domain in product design. Des Stud. 2004;25(6):547-77.

20. Rao RV. A material selection model using graph theory and matrix approach. Mater Sci Eng A. 2006;431(1-2):248-55.

21. Abeysundara UG, Babel S, Gheewala S. A matrix in life cycle perspective for selecting sustainable materials for buildings in Sri Lanka. Build Environ. 2009;44(5):997-1004.

22. Spiekermann C, Donath D. Digital support of material and product selection in the architectural design and planning process. In: Gürlebeck K, Könke C, editors. Proceeding of 17th International Conference on the Applications of Computer Science and Mathematics in Architecture and Civil Engineering; 2006 Jul 12-14; Weimar, Germany. Weimar (Germany): Bauhaus-University Weimar; 2006. p. 1-10.

23. Huang H, Zhang L, Liu Z, Sutherland JW. Multi-criteria decision making and uncertainty analysis for materials selection in environmentally conscious design. Int J Adv Manuf Technol. 2011;52(5-8):421-32.

24. Cheng K, Hsu SC, Li WM, Ma HW. Quantifying potential anthropogenic resources of buildings through hot spot analysis. Resour Conserv Recycl. 2018;133:10-20. 
25. Iffa E, Tariku F. Hygrothermal performance assessment of ICF walls with different moisture control strategies and wall designs. J. Green Build. 2017;12(4):35-53.

26. Uçtuğ FG, Ağralı S. Simple nonlinear optimization-based selection of insulation material and window type in Turkey: effect of heating and cooling base temperatures. J Green Build. 2017;9(6):79-94.

27. Wang J, Pan W. Influencing parameters of the life cycle cost-energy relationship of buildings. J Green Build. 2018;13(4):103-21.

28. Ajayia S, Oyedele LO, Ilori OM. Changing significance of embodied energy: A comparative study of material specifications and building energy sources. J Build Eng. 2019;23:324-33.

29. De Luca P, Carbone I, Nagy JB. Green building materials: a review of state of the art studies of innovative materials. J Green Build. 2017;12(4):141-61.

30. Harish VSKV, Kumar A. A review on modeling and simulation of building energy systems. Renew Sust Ener Rev. 2016;56:1272-92.

31. Lawania K, Biswas WK. Achieving environmental friendly building envelope for Western Australia's housing sector: A life cycle assessment approach. Int J Sust Built Environ. 2016;5(2):210-24.

32. Pillai RG, Gettu R, Santhanam M, Rengaraju S, Basavaraj AS. Service life and life cycle assessment of reinforced concrete systems with limestone calcined clay cement (LC3). Cem Concr Res. 2019;118:111-9.

33. Huang B, Chen Y, McDowall W, Türkeli S, Geng Y. Embodied GHG emissions of building materials in Shanghai. J Clean Prod. 2019;210:777-85.

34. Glover J, Whilte DO, Langrish TAG. Wood versus concrete and steel in house construction. J For. 2002;100(8):34-41.

35. Petrovic B, Myhren JA, Zhang X, Wallhagen M, Eriksson O. Life Cycle Assessment of Building Materials for a Single-family House in Sweden. Energy Procedia. 2019;158:3547-52.

36. Tettey UYA, Dodoo A, Gustavsson L. Effect of different frame materials on the primary energy use of a multi storey residential building in a life cycle perspective. Energy Build. 2019;185(15):259-71.

37. Göswein V, Goncalves AB, Silvestre JD, Freire F, Kurda R. Transportation matters-does it? GIS-based comparative environmental assessment of concrete mixes with cement, fly ash, natural and recycled aggregates. Resour Conserv Recycl. 2018;137:1-10.

38. Siddique R, Singh G, Belarbi R, Ait-Mokhtar K, Kunal. Comparative investigation on the influence of spent foundry sand as partial replacement of fine aggregates on the properties of two grades of concrete. Constr Build Mater. 2015;83:216-22.

39. Bhardwaj B, Kumar P. Waste foundry sand in concrete: A review. Constr Build Mater. 2017;156:661-74.

40. Nath P, Sarker PK. Effect of GGBFS on setting, workability and early strength properties of fly ash geopolymer concrete cured in ambient condition. Constr Build Mater. 2014;66:163-71. 
41. Durgun MY, Sevinc AH. High temperature resistance of concretes with GGBFS, waste glass powder, and colemanite ore wastes after different cooling conditions. Constr Build Mater. 2019;196:66-81.

42. Wang Y, Suraneni P. Experimental methods to determine the feasibility of steel slag as supplementary cementitious materials. Constr Build Mater. 2019;204:458-67.

43. Guo Y, Xie J, Zhao J, Zuo K. Utilization of unprocessed steel slag as fine aggregate in normal- and high-strength concrete. Constr Build Mater. 2019;204:41-9.

44. Tripathi B, Misra A, Chaudhary S. Strength and abrasion characteristics of ISF slag concrete. J Mater Civ Eng. 2013;25(11):1611-8.

45. Lori AR, Hassani A, Sedghi R. Investigating the mechanical and hydraulic characteristics of pervious concrete containing copper slag as coarse aggregate. Constr Build Mater. 2019;197:130-42.

46. Prem PR, Verma M, Ambily PS. Sustainable cleaner production of concrete with high volume copper slag. J Clean Prod. 2018;193:43-58.

47. Abdulmatin A, Tangchirapat W, Jaturapitakkul C. An investigation of bottom ash as a pozzolanic material. Constr Build Mater. 2018;186:155-62.

48. Ghosh A, Ghosh A, Neogi S. Reuse of fly ash and bottom ash in mortars with improved thermal conductivity performance for buildings. Heliyon. 2018;4(11):e00934.

49. Nath P, Sarker PK, Biswas WK. Effect of fly ash on the service life, carbon footprint and embodied energy of high strength concrete in the marine environment. Energy Build. 2018;158:1694-702.

50. Tamimi A, Hassan NM, Fattah K, Talachi A. Performance of cementitious materials produced by incorporating surface treated multiwall carbon nanotubes and silica fume. Constr Build Mater. 2016;114:934-45.

51. Muthusamy K, Mirza J, Zamri NA, Hussin MW, Budiea AMA. Properties of high strength palm oil clinker lightweight concrete containing palm oil fuel ash in tropical climate. Constr Build Mater. 2018;199:163-77.

52. Qin L, Gao X, Chen T. Recycling of raw rice husk to manufacture magnesium oxysulfate cement based lightweight building materials. J Clean Prod. 2018;191:220-32.

53. Umasabor RI, Okovido JO. Fire resistance evaluation of rice husk ash concrete. Heliyon. 2018;4(12):e01035.

54. Danso H. Properties of Coconut, Oil Palm and Bagasse Fibres: As Potential Building Materials. Procedia Eng. 2017;200:1-9.

55. Langade S, Gilke N, Patil K. Bagasse Ash for Manufacturing Construction Products. Materials Today Proceedings. 2018;5(9):19954-62.

56. Saccani A, Manzi S, Lancellotti I, Lipparini L. Composites obtained by recycling carbon fibre/epoxy composite wastes in building materials. Constr Build Mater. 2019;204:296-302.

57. Gómez-Soberón JM, Cabrera-Covarrubias FG, Almaral-Sánchez JL, GómezSoberón MC. Fresh-State Properties of Mortars with Recycled Glass Aggregates: Global Unification of Behavior. Adv Mater Sci Eng. 2018;2018:1386946. doi: 10.1155/2018/1386946 
58. Mendivil-Escalante JM, Gómez-Soberón JM, Almaral-Sánchez JL, CabreraCovarrubias FG. Metamorphosis in the Porosity of Recycled Concretes Through the Use of a Recycled Polyethylene Terephthalate (PET) Additive. Correlations between the Porous Network and Concrete Properties. Materials. 2017;10:176.

59. Cabrera-Covarrubias FG, Gómez-Soberón JM, Almaral-Sánchez JL, Arredondo-Rea SP, Gómez-Soberón MC, Corral-Higuera R. An Experimental Study of Mortars with Recycled Ceramic Aggregates: Deduction and Prediction of the Stress-Strain. Materials. 2016;9(12):1029.

60. Lawania K, Sarker PK, Biswas WK. Global Warming Implications of the Use of By-Products and Recycled Materials in Western Australia's Housing Sector. Materials. 2015;8(10):6909-25.

61. Ding T, Xiao J, Tam VWY. A closed-loop life cycle assessment of recycled aggregate concrete utilization in China. Waste Manag. 2016;56:367-75.

62. Hossain MU, Poon CS, Lo IC, Cheng JP. Evaluation of environmental friendliness of concrete paving eco-blocks using LCA approach. Int J Life Cycle Assess. 2016;21(1):70-84.

63. Braga AM, Silvestre JD, Brito JD. Compared environmental and economic impact from cradle to gate of concrete with natural and recycled coarse aggregates. J Clean Prod. 2017;162:529-43.

64. Yazdanbakhsh A, Bank LC, Baez T, Wernick I. Comparative LCA of concrete with natural and recycled coarse aggregate in the New York City area. Int J Life Cycle Assess. 2018;23(6):1163-73.

65. Grant A, Ries R, Kibert C. Life cycle assessment and service life prediction: A case study of building envelope materials. J Ind Ecol. 2014;18(2):187-200.

66. Maslesa E, Jensen PA, Birkved M. Indicators for quantifying environmental building performance: A systematic literature review. J Build Eng. 2018;19:552-60.

67. Gray J, Isaacs N, Kernohan D, McIndoe G. Building Evaluation techniques. Baird G, editor. New York (US): McGraw-Hill Co. Inc.; 1995.

68. ISO 15686-2, Buildings and constructed assets-Service life Planning. Part-2: Service life prediction procedures. Geneva (Switzerland): International Standards Organisation; 2012.

69. Madrigal LO, Bretones JF, Lanzarote BS. Proposed method of estimating the service life of building envelopes. J Constr. 2015;14(1):60-88.

70. Emídio F, Brito JD, Gaspar PL, Silva A. Application of the factor method to the estimation of the service life of natural stone cladding. Constr Build Mater. 2014;66:484-93.

71. Souza J, Silva A, Brito JD, Bauer E. Service life prediction of ceramic tiling systems in Brasília-Brazil using the factor method. Constr Build Mater. 2018;192:38-49.

72. Lyu Y, Kim JH, Gu X. Developing methodology for service life prediction of PV materials: Quantitative effects of light intensity and wavelength on discoloration of a glass/EVA/PPE laminate. Solar Energy. 2018;174:515-26. 
73. Ligotski R, Sager U, Schneiderwind U, Asbach C, Schmidt F. Prediction of VOC adsorption performance for estimation of service life of activated carbon based filter media for indoor air purification. Build Environ. 2019;149:146-56.

74. Prieto AJ, Silva A, Brito JD, Macías-Bernal JM, Alejandre FJ. Multiple linear regression and fuzzy logic models applied to the functional service life prediction of cultural heritage. J Cult Herit. 2017;27:20-35.

75. Rauf A, Crawford RH. The relationship between material service life and the life cycle energy of contemporary residential buildings in Australia. Arch Sci Rev. 2013;56(3):252-61.

76. Rauf A, Crawford RH. The Effect of Material Service Life on the Life Cycle Embodied Energy of Multi-Unit Residential Buildings. Paper presented at: World Sustainable Buildings WSB14 Conference; 2014 Oct 28-30; Barcelona, Spain.

77. Rauf A, Crawford RH. Building service life and its effect on the life cycle embodied energy of buildings. Energy. 2015;79:140-8.

78. Klöppfer W. Life Cycle Sustainability assessment of products. Int J Life Cycle Assess. 2008;13:89-95.

79. ISO 14040: Environmental management-Life cycle assessment-Principles and framework. Geneva (Switzerland): International Standards Organization; 2006.

80. Counsoli F, Allen D, Boustead I, Fava J, Franklin W, Jensen A. SETAC (Society) and LCA "Code of Practice” Workshop (1993: Sesimbra, Portugal) Guidelines for life-cycle assessment: a "code of practice". 1st ed. Pensacola (US): Society of Environmental Toxicology and Chemistry (SETAC); 1993.

81. Guinee JB, Haes UD, Huppes G. Quantitative life cycle assessment of products: 1: goal definition and inventory. J Clean Prod. 1993;1(1):3-13.

82. Bekker PCF. A life cycle approach in building. Build Environ. 1982;17(1):3-13.

83. Coles RJ. Energy and greenhouse gas emissions associated with the construction of alternative structural systems. Build Environ. 1998;34(3): 335-48.

84. Fufa SM, Skaar C, Gradeci K, Labonnote N. Assessment of greenhouse gas emissions of ventilated timber wall constructions based on parametric LCA. J Clean Prod. 2018;44:319-33.

85. Marjaba GE, Chidiac SE. Sustainability and resiliency metrics for buildingsCritical review. Build Environ. 2016;101:116-25.

86. Rakha T, Moss TW, Shin D. A decade analysis of residential LEED buildings market share in the United States: Trends for transitioning sustainable societies. Sustain Cities Soc. 2018;39:568-77.

87. Saldaña-Márquez H, Gómez-Soberón JM, Arredondo-Rea SP, Rosell-Balada G. The passivhaus standard in the mediterranean climate: Evaluation, comparison and profitability. J Green Build. 2015;10(4):55-72.

88. Saldaña-Márquez H, Gómez-Soberón JM, Arredondo-Rea SP, Gámez-García DC, Corral-Higuera R. Sustainable social housing: The comparison of the Mexican funding program for housing solutions and building sustainability rating systems. Build Environ. 2018;133:103-22. 
89. Fouquet M, Levasseur A, Margni M, Lebert A, Lasvaux S, Souyri B, et al. Methodological challenges and developments in LCA of low energy buildings: Application to biogenic carbon and global warming assessment. Build Environ. 2015;90:51-9.

90. Motuziene V, Rogoža A, Lapinskiene V, Vilutiene T. Construction solutions for energy efficient single-family house based on its life cycle multi-criteria analysis: A case study. J Clean Prod. 2016;112:532-41.

91. Aneurin Grant RR. Impact of building service life models on life cycle assessment. Build Res Info. 2013;41(2):168-86.

92. Akadiri PO. Understanding barriers affecting the selection of sustainable materials in building projects. J Build Eng. 2015;4:86-93.

93. Ingrao C, Arcidiacono C, Bezama A, Ioppolo G, Schmid AG. Virtual Special Issue on sustainability issues of by-product and waste management systems to produce building material commodities. Resour Conserv Recycl. 2017;126:A4-5.

94. Gámez-García DC, Gómez-Soberón JM, Corral-Higuera R, Saldaña-Márquez H, Gómez-Soberón MC, Arredondo-Rea SP. A Cradle to Handover Life Cycle Assessment of External Walls: Choice of Materials and Prognosis of Elements. Sustainability. 2018;10(8):2748.

95. Maalouf C, Ingrao C, Scrucca F, Moussa T, Asdrubali F. An energy and carbon footprint assessment upon the usage of hemp-lime concrete and recycled-PET façades for office facilities in France and Italy. J Clean Prod. 2018;170:1640-53.

96. Intini F, Kühtz S. Recycling in buildings: an LCA case study of a thermal insulation panel made of polyester fiber, recycled from post-consumer PET bottles. Int J Life Cycle Assess. 2011;16(4):306-15.

97. Schmidt M, Crawford RH. A framework for the integrated optimisation of the life cycle greenhouse gas emissions and cost of buildings. Energy Build. 2018;171:155-67.

98. Tam WV, Le KN, Tran CN, Wang JY. A review on contemporary computational programs for Building's life-cycle energy consumption and greenhouse-gas emissions assessment: An empirical study in Australia. J Clean Prod. 2018;172:4220-30.

99. Martínez-Rocamora A, Solís-Guzmán J, Marrero M. LCA databases focused on construction materials: A review. Renew Sustain Energy Rev. 2016;58:565-73.

100. Frischknecht R, Jungbluth N, Althaus HJ, Doka G, Dones R, Heck T, et al. The ecoinvent database: Overview and methodological framework. Int J Life Cycle Assess. 2005;10(1):3-9.

101. Ecoinvent Centre. Ecoinvent Databases 2019. Available from: http://www.ecoinvent.org/database/database.html. Access 2019 Apr 28.

102. Thinkstep. GaBi Databases 2019. Available from: http://www.gabisoftware.com/databases/gabi-databases/. Access 2019 Apr 28.

103. Crawford RH, Czerniakowski I, Fuller RJ. A comprehensive framework for assessing the life-cycle energy of building construction assemblies. Arch Sci Rev. 2010;53(3):288. 
104. Blengini GA, Carlo TD. Energy-Saving policies and low-energy residential buildings: an LCA case study to support decision makers in Piedmont (Italy). Int J Life Cycle Assess. 2010;15(7):652-65.

105. Vitale P, Arena N, Gregorio F, Arena U. Life cycle assessment of the end-of-life phase of a residential building. Waste Manag. 2017;60:311-21.

106. Ghose A, Pizzol M, McLaren S. Consequential LCA modelling of building refurbishment in New Zealand-an evaluation of resource and waste management scenarios. J Clean Prod. 2017;165:119-33.

107. Zhou C, Dai X, Wang R, Huang J. Indicators for evaluating sustainable communities: A review. Acta Ecol Sin. 2011;31(16):4750-9.

108. Geng S, Wang Y, Zuo J, Zhou Z, Mao G. Building life cycle assessment research: A review by bibliometric analysis. Renew Sustain Energy Rev. 2017;76:176-84.

109. Settanni E, Tassielli G, Notarnicola B. Life Cycle Costing (LCC). In: Spellerberg I, Fogel DS, Fredericks SE, Butler Harrington LM, editors. Berkshire ENCYCLOpaedia of SUSTainability 6/10: Measurements, Indicators, and Research Methods for Sustainability. Great Barrington (US): Berkshire Publishing Group; 2012. p. 225-7.

110. HuaGoh B, Sun Y. The development of life-cycle costing for buildings. Build Res Inf. 2016;44(3):319-33.

111. Lawania K, Biswas WK. Cost-effective GHG mitigation strategies for Western Australia’s housing sector: A life cycle management approach. Clean Technol Environ Policy. 2016;18(8):2419-28.

112. Heijungs R, Settanni E, Guinée J. Toward a computational structure for life cycle sustainability analysis: Unifying LCA and LCC. Int J Life Cycle Assess. 2012;18(9):1722-33.

113. Singh D, Tion RK. Development of life cycle costing framework for highway bridges in Myanmar. Int J Project Manag. 2005;23(1):37-44.

114. Cuellar-Franca RM, Azapagic A. Life cycle cost analysis of the UK housing stock. Int J Life Cycle Assess. 2014;19:174-93.

115. Kovacic I, Waltenbereger L, Gourlis G. Tool for life cycle analysis of facadesystems for industrial buildings. J Clean Prod. 2016;130(1):260-72.

116. Azeem S, Naeem MA, Waheed A, Thaheem MJ. Examining barriers and measures to promote the adoption of green building practices in Pakistan. Smart Sustain Built Environ. 2017;6(3):86-100.

117. Persson J, Grönkvist S. Drivers for and barriers to low-energy buildings in Sweden. J Clean Prod. 2015;109:296-304.

118. Shen LY, Hao JL, Tam VW, Yao H. A checklist for assessing sustainability performance of construction projects. J Civil Eng Manag. 2007;13(4):273-81.

119. Ahmad T, Thaheem MJ. Economic sustainability assessment of residential buildings: A dedicated assessment framework and implications for BIM. Sustain Cities Soc. 2018;38:476-91.

120. Babaizadeh H, Haghighi N, Asadi A, Broun R, Riley D. Life cycle assessment of exterior window shadings in residential buildings in different climate zones. Build Environ. 2015;90:168-77.

121. Allacker K, Trigaux D, Troyer FD. An Approach For Handling Environmental And Economic Conflicts In The Context Of Sustainable Building. In: Passerini 
G, Brebbia CA, editors. Environ Impact II. WIT Transactions on Ecology and the Environment. Southampton (UK): WIT Press; 2014. p. 79-90.

122. Chiang YH, Li J, Zhou L, Wong FK, Lam PT. The nexus among employment opportunities, life-cycle costs, and carbon emissions: A case study of sustainable building maintenance in Hong Kong. J Clean Prod. 2015;109: 326-35.

123. Dawood MH. BIM based optimal life cycle cost of sustainable house framework. In: Proceedings of 3rd MEC International Conference on Big Data and Smart City; 2016 Mar 15-16; Muscat, Oman. Piscataway (US): IEEE; 2016. doi: 10.1109/ICBDSC.2016.7460381

124. Sayed M, Sajid S, Sawant, Priyadarshi H. Financial feasibility analysis of water conservation components in mass housing projects: Suburban Indian Case review. J Arch Eng. 2016;22(2):e04016001-1.

125. Tam VWY, Senaratne S, Le KN, Shen LY, Perica J, Illankoon IMCS. Life-cycle cost analysis of green-building implementation using timber applications. J Clean Prod. 2017;147:458-69.

126. Yoshida J, Sugiura A. The Effects of Multiple Green Factors on Condominium Prices. J Real Estate Finan Econ. 2015;50(3):412-37.

127. Roh S, Tae S, Kim R. Development of a Streamlined Environmental Life Cycle Costing Model for Buildings in South Korea. Sustainability. 2018;10(6):1733.

128. O’Brien M, Doig A, Clift R. Social and environmental life cycle assessment (SELCA): approach and methodological development. Int J Life Cycle Assess 1996;1(4):231-37.

129. United Nations Environment Programme. Guidlines for Social Life Cycle Assessment of Products. Paris (France): Life Cycle initiative, 2009. Available from: $\quad$ https://www.lifecycleinitiative.org/starting-life-cycle-thinking/lifecycle-approaches/social-lca. Accessed 2018 Jun 30.

130. Ekener-Petersen E, Finnveden G. Potential hotspots identified by social LCA Part 1: A case study of a laptop computer. Int J Life Cycle Assess. 2013;18(1):127-43.

131. Ekener E, Hansson J, Gustavsson M. Addressing positive impacts in social LCA discussing current and new approaches exemplified by the case of vehicle fuels. Int J Life Cycle Assess. 2018;23(3):556-68.

132. Manik Y, Leahy J, Halog A. Social life cycle assessment of palm oil biodiesel: A case study in Jambi Province of Indonesia. Int J Life Cycle Assess. 2013;18(7):1386-92.

133. Lim CI, Biswas WK. An Evaluation of Holistic Sustainability Assessment Framework for Palm Oil Production in Malaysia. Sustainability. 2015;7: 16561-7. doi: 10.3390/su71215833

134. Agyekum EO, Fortuin K, Harst ED. Environmental and social life cycle assessment of bamboo bicycle frames made in Ghana. J Clean Prod. 2017;143:1069-80.

135. Santos AC, mendes P, Teixeira MR. Social life cycle analysis as a tool for sustainable management of illegal waste dumping in municipal services. J Clean Prod. 2019;210:1141-9. 
136. Martínez-Blanco J, Lehmann A, Muñoz P, Antón A, Traverso M, Rieradevall J, et al. Application challenges for the social Life Cycle Assessment of fertilizers within life cycle sustainability assessment. J Clean Prod. 2014;69:34-48.

137. Hosseinijou SA, Mansour S, Shirazi MA. Social life cycle assessment for material selection: a case study of building materials. Int J Life Cycle Assess. 2014;19(3):620-45.

138. Dong YH, Ng ST. A social life cycle assessment model for building construction in Hong Kong. Int J Life Cycle Assess. 2015;20(8):1166-80.

139. Santos P, Pereira AC, Gervásio H, Bettencourt A, Mateus D. Assessment of health and comfort criteria in a life cycle social context: Application to buildings for higher education. J Clean Prod. 2017;123:625-48.

140. European Committee for Standardisation. EN 16309:2014+A1, Sustainability of Construction Works-Assessment of Social Performance of BuildingsCalculation Methodology. Brussels (Belgium): CEN-European Committee for Standardisation; 2014.

141. Liu S, Qian S. Evaluation of social life-cycle performance of buildings: Theoretical framework and impact assessment approach. J Clean Prod. 2019;213:792-807.

142. Mathe S. Integrating participatory approaches into social life cycle assessment. The SLCA participatory approach. Int J Life Cycle Assess. 2014;19(8):1506-14.

143. Dong YH, Ng ST. A modeling framework to evaluate sustainability of building construction based on LCSA. Int J Life Cycle Assess. 2016;21:555-68.

144. Fu F, Pan L, Ma L, Li Z. A simplified method to estimate the energy-saving potentials of frequent construction and demolition process in China. Energy. 2013;49:316-22.

145. Griggs D, Smith MS, Gaffney O, Rockström J, Öhman MC, Shyamsundar P, et al. Sustainable development goals for people and planet. Nature. 2013;495(7441):305-7.

146. Bragança L, Mateus R, Koukkari H. Building Sustainability Assessment. Sustainability. 2010;2:2101-23.

147. Alwaer H, Clements-Croome DJ. Key performance indicators (KPIs) and priority setting in using the multi-attribute approach for assessing sustainable intelligent buildings. Build Environ. 2010;45(4):799-807.

148. Dale VH, Beyeler SC. Challenges in the development and use of ecological indicators. Ecol Indic. 2001;1(1):3-10.

149. Lasvaux S, Achim F, Garat P, Peuportier B, Chevalier J, Habert G. Correlations in Life Cycle Impact Assessment methods (LCIA) and indicators for construction materials: what matters? Ecol Indic. 2016;67:174-82.

150. Kamali M, Hewage K, Milani AS. Life cycle sustainability performance assessment framework for residential modular buildings: Aggregated sustainability indices. Build Environ. 2018;138:21-41.

151. Onat NC, KucukvarM, Tatari O. Integrating triple bottom line input-output analysis into life cycle sustainability assessment framework: the case for US buildings. Int J Life Cycle Assess. 2014;19:1488-505. 
152. Balasbaneh AT, Bin Marsono AK, Kermanshahi KE. Balancing of life cycle carbon and cost appraisal on alternative wall and roof design verification for residential building. Constr Innovation. 2018;18(3):274-300.

153. Hossaini N, Reza B, Akhtar S, Sadiq R, Hewage K. AHP based life cycle sustainability assessment (LCSA) framework: a case study of six storey wood frame and concrete frame buildings in Vancouver. J Environ Plan Manag. 2015;58(7):1217-41.

How to cite this article:

Janjua SY, Sarker PK, Biswas WK. A Review of Residential Buildings' Sustainability Performance Using a Life Cycle Assessment Approach. J Sustain Res. 2019;1:e190006. https://doi.org/10.20900/jsr20190006 